\title{
Engraftment of pre-differentiated stem cells into cardiomyocytes in an animal model of ischemic cardiopathy
}

\author{
Maria Teresa Gonzalez-Garza*, Citlali Alcaraz, Lizbeth Gonzalez-Jara, \\ Demetrio Arcos, Jorge E. Moreno Cuevas
}

Servicio de Terapia Celular, School of Medicine, Centro de Innovación y Transferencia en Salud, Tecnológico de Monterrey, Monterrey, México; *Corresponding Author: mtgonzalezgarza@itesm.mx

Received 6 November 2013; revised 27 November 2013; accepted 4 December 2013

Copyright (C 2014 Maria Teresa Gonzalez-Garza et al. This is an open access article distributed under the Creative Commons Attribution License, which permits unrestricted use, distribution, and reproduction in any medium, provided the original work is properly cited. In accordance of the Creative Commons Attribution License all Copyrights (C 2014 are reserved for SCIRP and the owner of the intellectual property Maria Teresa Gonzalez-Garza et al. All Copyright (C) 2014 are guarded by law and by SCIRP as a guardian.

\section{ABSTRACT}

Stem cell therapy for cardiac infarct regeneration has been widely used in clinical research. Despite the fact that important advances in this field have been reached, the observed recovery does not demonstrate new cardiac muscle formation. Benefits have been observed due to an improvement in neovascularisation. The main objective of this study was to determine if predifferentiated stem cells into cells of myocardic lineage are capable of engraftment in animal models with induced cardiac infarct and are capable of truly differentiating into myocardiocytes. Bone marrow rat stem cells were predifferentiated with 5-AZ. After 4 weeks, pre-differentiated stem cells express muscarinic 1, 2 and $\beta$ adrenergic 2 receptors. Also, proteins such as sarcomeric $\alpha$-actin, cardiac myosin heavy chain, desmin and vimentin were detected by immunocytochemistry. Cells were transplanted intracardialy in an ischemic cardiac rat model. Pre-differentiated or non differentiated cells were transplanted after 4 weeks post infarct induction. Histopathology of the hearts was made 2 weeks after cell transplantation. Typical granulated tissue, scare formation and neovascularisation were observed in both groups. However, in those hearts from rats inoculated with pre-differentiated cells many appeared atypical and were $\alpha$-actin sarcomeric positive. These events suggest that pre-differentiated cells conserve some muscle characteristic traits in situ that at least last for two weeks after transplantation.

\section{KEYWORDS}

Cell Therapy; MSC; Regenerative Medicine; Cardiocyte Differentiation; Stem Cells

\section{INTRODUCTION}

Myocardial infarction is the leading cause of heart failure in developed countries. Even advanced therapeutic measures are usually not sufficient to prevent left ventricular remodeling as they fall short of replacing necrotic cardiac myocytes. Recent insights into stem cell biology have changed our understanding of regenerative activities in the infarcted heart and have raised considerable hopes for novel therapeutic approaches aimed at cardiac myocyte replacement/regeneration through cell transplantation.

Considering this fact, stems cells have been used for autologous transplant in several clinical trials for repair of the ischemic myocardium. The results show heart function improvement after stem cells transplantation [1-11]. However, It remains unclear which stem cell(s) can contribute to these effects on the myocardium, and whether they do so by trans-differentiation or cell fusion [12]. It has been suggested that this improvement of heart function has been the result of angiogenic effects more than the generation of new cardiac muscle [13].

Several reports of stem cells application into damage hearts have been made, but until now there is no a general consensus of what specific type of the generally named stem cells is the best option. Comparing the relative efficacies to facilitate recovery of cardiac damage, 
different cells types have been studied: Bone marrow (BM) mononuclear cells showed to be more effective than BM mesenchymal stem cells (MSC) [14] and adult blood stem cells were more effective than cord blood stem cells [14]. Adipose derived stem cells (ASCs) have also been used for repair in myocardial infarction. Comparing the in vivo behavior of ASCs and MSCs in the necrotic heart demonstrated that, in general, both populations of stem cells do not tolerate the cardiac environment, resulting in acute donor cell death and a subsequent loss of cardiac function similar to control groups. Nevertheless, some tolerance, although not ideal, was observed with CD133 ${ }^{+}$MSCs [15]. According to Davy et al. [16] enrichment of autologous bone marrow CD34 ${ }^{+}$ stem cells could increase the efficacy of treatments in clinical settings. Despite the fact that $\mathrm{CD}_{3} 4^{+}$cells have been the selected option for heart repair, there are also some reports of $\mathrm{CD}_{133^{+}}$cells applied in clinical trials showing improvement of myocardial viability and local perfusion of the infarcted zone [17-22]. However, none of these studies have shown de novo formation of cardiac muscle.

On the other hand, it has demonstrated the capacity of adult stem cells for in vitro differentiation into cardiomyocytes. This possibility presents an alternative approach for transplant protocols of stem cells going into cardiomyocytes instead of using undifferentiated stem cells. 5-azacitidin (5-AZ) or its derivatives were reported to induce cardiac differentiation in vitro of mesenchymal stem cells derived from bone marrow and embryonic cells [23-27].

Hakuno report that differentiated mesenquimal cells derived from the bone marrow (CMGs) express $\beta$-adrenergic receptors as well as muscarinic M1 and M2 receptors [24]. Furthermore, stimulation of CMG cells with phenylephrine, isoproterenol, or carbachol could activate downstream signalling pathways through specific receptors. Temporal expression of $\beta 1$ - and $\beta 2$-adrenergic and M1 and M2 muscarinic receptors was reported [23]. The main objective of this study was to determinate if predifferentiated stem cells into myocardic lineage cells are capable of engraftment in animal models with induced cardiac infarct and truly differentiate in myocadiocytes, instead of endothelial cells.

\section{MATERIALS AND METHODS}

\subsection{Isolation, Expansion, and Myocardial Induction of Rat Bone Marrow-Derived Stem Cells}

Female Winstar rats were anesthetized with ether, thigh bones were excised, and bone marrow cells were obtained. Cells were cultured for 24 hs on $60-\mathrm{mm}$ dishes in Dulbecco's Modification of Eagle's medium (DMEM-
F12) (GIBCO BRL) supplemented with 20\% fetal bovine sera (FBS) and penicillin $(100 \mu \mathrm{g} / \mathrm{ml}) /$ streptomycin (250 $\mathrm{ng} / \mathrm{ml})$ at $37^{\circ} \mathrm{C}$ in humid air with $5 \% \mathrm{CO}_{2}$. After that the media were change and maintained in DMEM-F12 medium supplemented with 10\% FBS and antibiotics for several weeks.

\subsection{Stem Cell Culture and 5-AZ Treatment}

To induce cell differentiation, cells from the third passage were incubated in DMEM-F12 medium supplemented with 5\% FBS and antibiotics $24 \mathrm{~h}$ before treatment with $3 \mu \mathrm{mol} / \mathrm{l}$ of 5-azacytidine (Sigma Chemical Co., St. Louis, Missouri, USA) for 24 hours. After incubation, media were change and maintained on DMEMF12 medium supplemented with 10\% FBS and antibiotics for four weeks. In week 4, these cells were used for RT-PCR expression of muscarinic and adrenergic receptor, immunodetection of myosin, actin, desmin and vimetin, and animal transplantation.

\subsection{Reverse Transcription-Polymerase Chain for Myocardial Receptors}

Total RNA from 1 to 10 weeks after 5-AZ induction cells was extracted with GenElute mammalian total RNA (Sigma Chemical Co., St. Louis, Missouri, USA). Reverse transcription-polymerase chain reaction (RT-PCR) was performed with OneStep RT-PCR Kit (Qiagen). Amplification was performed for genes responsable for the expressions of $\beta 1 \mathrm{~A}, \beta 1 \mathrm{~B}, \mathrm{M} 1$, and $\mathrm{M} 2$ receptors. The primers used are listed in Table 1. HRTP was used as an internal control for each sample.

\subsection{Immunocytochemistry for Myocardial Proteins}

Myocardiocytes protein synthesis was analized by immunostaining with monoclonal antibody (MF20) to sarcomeric $\alpha$-actin, cardiac myosin heavy chain, desmin,

Table 1. Primers used for gene expression.

\begin{tabular}{cc}
\hline Gene & Primer sequence (5'-3') forward \\
\hline$\beta 1$ (Forward) & 5'ACGCTCACCAACCTCTTCAT3' \\
(Reverse) & 5'AGGGGCACGTAGAAGGAGAC3' \\
$\beta 2$ (Forward) & 5'CCTCATGTCGGTTATCGTCC3' \\
(Reverse) & 5'GGCACGTAGAAAGACACAATC3 \\
M1 (Forward) & 5'CTGGTTTCCTTCGTTCTCTG3' \\
(Reverse) & 5' GCTGCCTTCTTCTCCTTGAC3' \\
M2 (Forward) & 5'GGCAAGCAAGAGTAGAATAAA3' \\
(Reverse) & 5'GCCAACAGGATAGCCAAGATT3' \\
\hline
\end{tabular}


and vimentin (Sigma Chemical Co., St. Louis, Missouri, USA). Cells grown on glass coverslips were fixed with $-20^{\circ} \mathrm{C}$ methanol and permeabilized with $0.3 \%$ Tritón X-100 (Sigma Chemical Co., St. Louis, Missouri, USA) in PBS. After blocking with 5\% BSA in PBS for $1 \mathrm{~h}$ at room temperature, the cells were incubated with different fluorescent primary antibodies. Fluorescein/conjugated anti-mouse IgG (Pierce) were used as second antibody. Visualization was performed on epifluorescence AXIO IMAGER.Z1 microscope.

\subsection{Myocardial Infarction Induced in Wistar Rat}

Myocardic infarction was performed under anesthesia with an intraperitoneal injection of pentobarbital 40 $\mathrm{mg} / \mathrm{kg}$. Trichotomy was undertaken in the neck region. The neck dissection was carried out by planes into the trachea to culminate with a tracheostomy. A tracheal tube was placed (Jelco No. 16 Braun Introcan ${ }^{\circledR}$ ). Ventilation frequency and tidal volume for mechanically ventilated was calculated by positive pressure (Kent Scientific Dual Mode TopoM). Midline sternum incision was performed and dissected at all tissue levels to the bone. With slight pressure on the heart with an applicator or spatula, heart rate was decreased. Then we proceeded to perform a surgical obstruction midway of the left anterior descending coronary artery with 6-0 Prolene suture. At the end, closure of the rib cage in layers with Vicryl suture 5-0 was done.

\subsection{Stem Cells Transplantation into Rat Infarct Heart}

After 4 weeks of myocardial infarction, three groups consisting of six male Wistar rats each were established. Group I: Intracardiac injection at the site of infarct with PBS. Group II: Intracardiac injection at the site of infarct with non-differentiated stem cells. Group III. Intracardiac injection at the site of infarct with stem cells incubated in induction medium for 4 weeks (pre-differentitated to cardiocytes). The heart was exposed as previously described and $1 \times 10^{5} / 100 \mu$ l of non differentiated or pre-differentiated stem cells were injected in the infarcted area and proceeded to close as previous.

\subsection{Histologycal Analysis of Transplanted Rat Heart}

Four week after cells transplantation or PBS injection animals were sacrificed and hearts fixated with a solution of $10 \% \mathrm{PBS} /$ formaldehyde and embedded in paraffin. Serial sections were performed at the infarcted area. Lamella preparation was stained with hematoxylin/eosin and Masson trichrome stain for interpretation and evaluation of parameters of healing of the infarcted area.

\section{RESULTS}

\subsection{Cell Culture and 5-AZ Treatment}

Primary culture of stem cells recovered from the rat bone marrow showed characteristic CPU formation after 12 days incubation in DMEM-F12 medium (Figure 1(a)).

After 4 weeks of 5-AZ treatment the percentage of cardiomyocytes-like cells was approximately $30 \%$ to $50 \%$. In addition, there were important morphology changes on 5-AZ treated cells cultured after 3 weeks, containing large structures different to the ones observed in the colony formation units (CFU) or with the untreated cultures (Figure 1(b)).

\subsection{Immunodetection}

Four weeks after culture exposure to 5-AZA, the cells showed positive staining for vimentin (Figure 2(a)), cardiac myosin (Figure 2(b)), sarcomeric $\alpha$-actin (Figure 2(c)) and desmin (Figure 2(d)) by immunohistho-

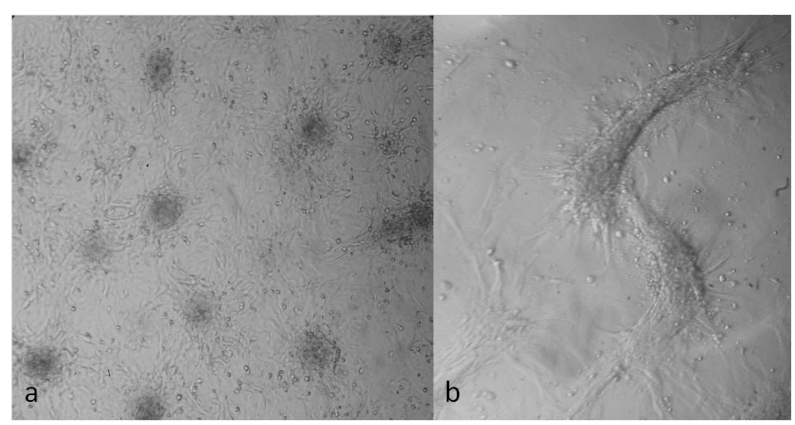

Figure 1. Primary cultures of rat bone marrow stem cells before and after 5-AZ incubation; (a) Several CFUs on a confluent plate after incubation for 12 days in DMEM-12 medium; (b) Morphological and disposition changes of organized cells on a plate, after 4 weeks of 5-AZ induction.

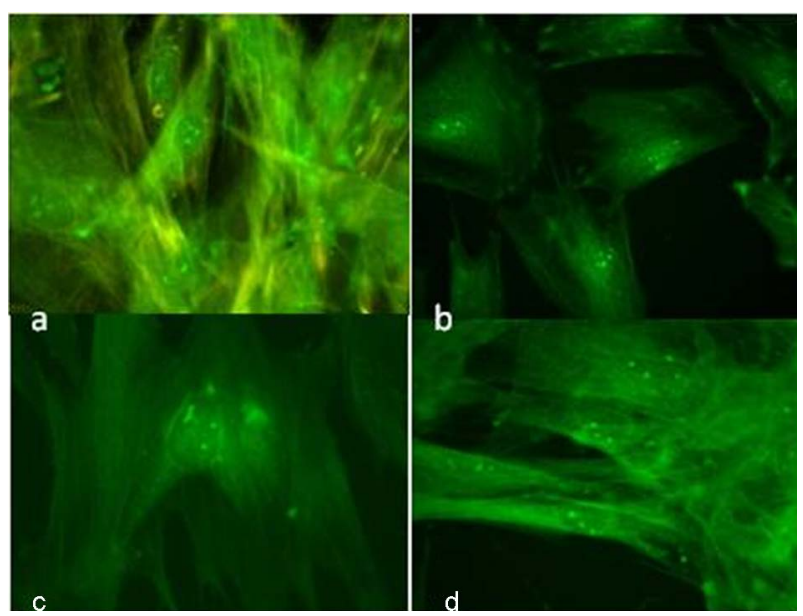

Figure 2. Microphotography of bone marrow stem cells in culture after 4 week of 5-AZ induction. Positive inmunostaining of cardiac proteins. Vimentin (a), cardiac myosin (b), $\alpha$-actin sarcomeric (c) and desmin (d) $100 \times$. 
chemistry (Figure 2).

\subsection{Reverse Transcription-Polymerase Chain}

RT-PCR showed the presence of muscarinic-2 receptor expression on differentiated stem cells that increased 4 weeks after 5-AZ treatment. Muscarinic -1 and 2 receptors were detected weakly until 4 weeks as well as the Adrenergic $\beta 2$ receptor. Adrenergic $\beta 1$ receptor was un-detected in any sample (Figure 3).

\subsection{Macroscopic and Microscopic Analysis of Myocardic Infarct Area after 2 Weeks of Stem Cells Transplantation}

All experimental groups showed macro-and microscopic evidence of acute myocardial infarction. In the hearts from control animals, a macroscopic area of graywhiteish scar progressing from the edge to the center of the infarct around the suture was observed (Figure 4(a)). This was less evident in hearts transplanted with predifferentiate stem cells (Figure 4(b)) or stem cells without differentiation (Figure 4(c)).

The histopathological analysis of the lesion confirmed the presence of a variable area of granulated tissue associated with replacement at different stages of fibrosis or scar tissue with abundant collagen deposition (Figures 5(a), (b)). The histopathological analysis of heart from animals which were transplanted with stem cells without

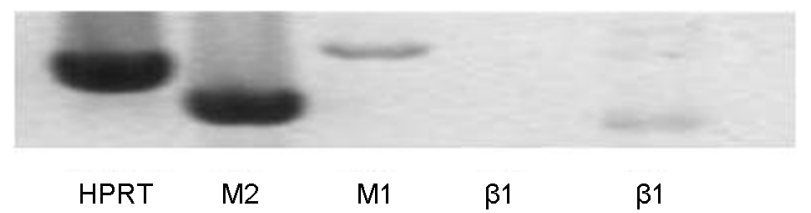

Figure 3. Detection by RT-PCR of the expression of Muscarinic 1 (M1), Muscarinic 2 (M2) and Adrenergic $\beta 2$ receptors on bone marrow stem cells after 4 week of 5-AZ induction.

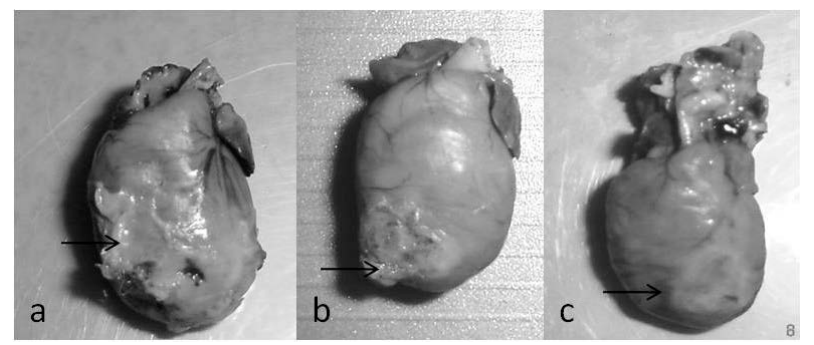

Figure 4. Macroscopic images of hearts frominfarcted rats. (a) The Heart from a rat of the control group showing an extended area of damage in the infarcted area; (b). Heart from a rat inoculated with $10^{5}$ of non- differentiated stem cells. It demonstrates a less extended area of damage in the infracted area; (c) Heart from a rat inoculated with $10^{5}$ of pre-differentiated stem cell. It demonstrates an apparent lesser damage in the infarcted area. differentiation show the presence of a variable area of granulation tissue associated with replacement at different stages of fibrosis or scar tissue with collagen deposition and vascular congestion (Figures 5(c), (d)). Hearts from rats transplanted with stem cells pre-differentiated to myocardiocytes present also a larger area of granulated tissue or neovascularization, however there was a significant presence of reactive fibroblasts and atypical cells (arrow) (Figures 5(e), (f)). Also the immunohistological analysis demonstrated that the atypical cells, than do not resemble cardic muscle fiber, were positive for sarcomeric actin (Figure 6).

\section{DISCUSSION}

It has been proposed that the benefit of stem cell transplantation on a myocardic infarct is owed to neo-vascularization, because these cells tend to differentiate into endothelial cells instead of cardiocytes. The aim of this work was to analyze the possibility of true myocardial cell engrafment if pre-diferendiated cardiocytes, or undifferentiated stem cells were used. The pluripotency and plasticity of stem cells had been de-

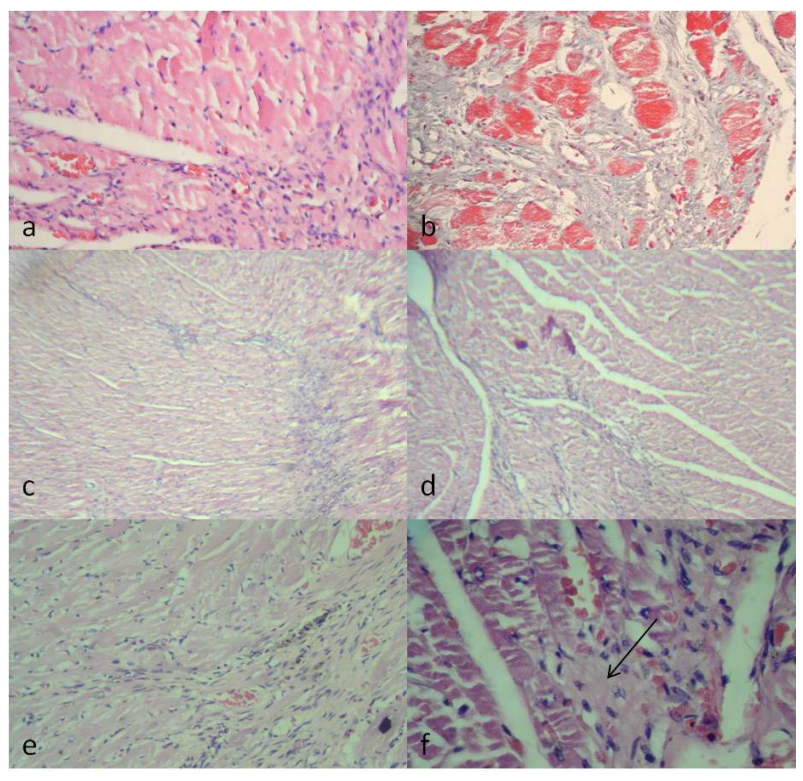

Figure 5. Light micrographs of transversal ventricular sections. (a) Rat infarct heart 2 weeks after injecting PBS. The Hematoxylin \& Eosin staining of this heart exhibits increased interstitial fibrosis, granulation and vascular congestion; (b) Rat infarct heart 2 weeks after injecting PBS. Masson Trichromic staining exhibit high collagen content; (c) Rat infarct heart 2 weeks after the injection of undifferentiated bone marrow stem cells. Hematoxylin \& Eosin staining of this heart exhibit granulation; (d) Rat infarct heart 2 weeks after injecting undifferentiated bone marrow stem cells. Masson Trichromic staining of this heart exhibit collagen deposit; (e) Rat infarct heart 2 weeks after injecting predifferentiated bone marrow stem cells. Hematoxylin \& Eosin staining of this heart exhibit granulation; (f) atypical cells. 


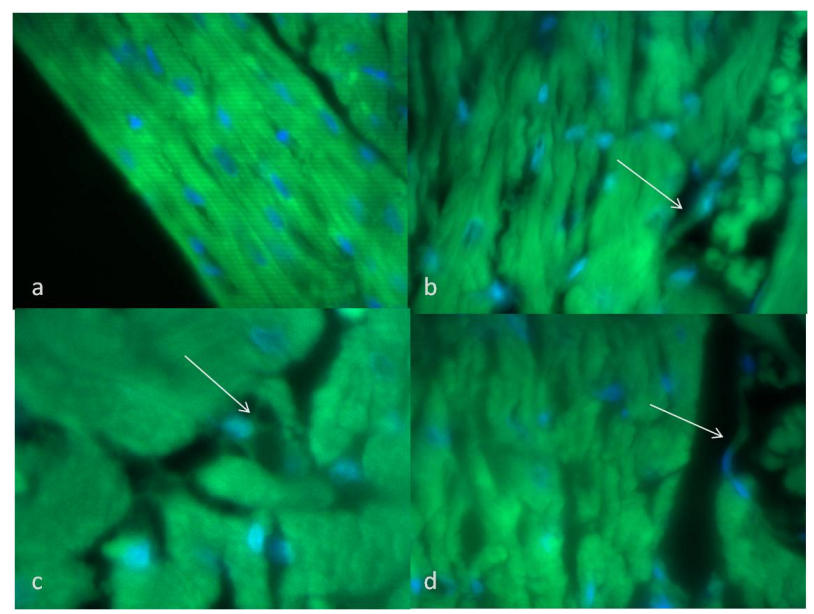

Figure 6. Inmunohistological detection of sarcomeric actin (a) Positive inmunostaining against $\alpha$-actin sarcomeric in normal cardiac tissue; (b)-(c) Histological view of experimental heart after pre-induced miocardic cells transplantation showing altered histology area and atypical cells (arrow).

monstrated. Also it has been shown that depending on the signals in the environment the cells can differentiate into specific cell lineages [26-30]. Reports of stem cells transplanted into animal models which described an increase in vascular tissue, but not of cardiac muscle mass are available [13]. This could be a consequence of the presence of inflammatory macrophages at the niche or implantation site. By inducing the formation of new vessels due to the activation of angiogenic signals by these cells, the transformation to endothelial cells instead of cardiocytes could be explained. However, if genes are switched on with anticipation into a cardiac lineage, the probability that these cells complete their differentiation into cardiomyocytes by transdifferentiation in situ, opens an interesting possibility for the true replacement of lost tissue. In fact, there is a report of autologous cardic stem cells transplantation in patients with heart failure of ischemic etiology, induce striking improvement in both global and regional left ventricular function, a reduction in infarct size, and an increase in viable tissue. However the isolation of the cardiac stem cells must be obtained during coronary artery bypass grafting [31-33]. However, the application of myocardiocytes precursors, could be an alternative. The results of this study demonstrate that stem cells stimulated with 5-AZ are capable of expressing specific cardiac protein such as actin, myosin, desmin and vimentin, as well as the expression of adrenergic and muscarinic receptors, but with no full differentiation into cardiomyocytes. The latter concept is important because the pre-differentiation could allow these cells to engraft correctly and contribute to an increase in cardiac muscle mass. The presence of atypical cells in the hearts of transplanted animals should be followed up more time in order to verify whether or not these atypical cells could transdifferentiate into new muscle tissue and not only in scar or vascular tissue.

\section{CONCLUSION}

Detection of atical cells $\alpha$-actin sarcomeric postive on cardic damage tissue after two weeks of animals transplanted with predifferentiated cells suggests that these cells could be a better option for heart repair.

\section{ACKNOWLEDGEMENTS}

This work was partially funded by endowments from Instituto Tecnológico de Estudios Superiores de Monterrey (cat-134) and the Zambrano-Hellion Foundation.

\section{REFERENCES}

[1] Hamano, K., Nishida, M., Hirata, K., Mikamo, A., Li, T.S., Harada, M., et al. (2001) Local implantation of autologous bone marrow cells for therapeutic angiogenesis in patients with ischemic heart disease: Clinical trial and preliminary results. Japanese Circulation Journal, 65, 845-847. http://dx.doi.org/10.1253/jcj.65.845

[2] Strauer, B.E., Brehm, M., Zeus, T., Köstering, M., Hernandez, A., Sorg, R.V., et al. (2002) Repair of infarcted myocardium by autologous intracoronary mononuclear bone marrow cell transplantation in humans. Circulation, 106, 1913-1918.

[3] Tamm, C., Westphal, B., Kleine, H.D., Petzsch, M., Kittner, C., Klinge, H., et al. (2003) Autologous bone marrow stem cell transplantation for myocardial regeneration. Lancet, 361, 45-46. http://dx.doi.org/10.1016/S0140-6736(03)12110-1

[4] Tse, H.F., Kwong, Y.L., Chan, J.K.F., Lo, G., Ho, C.L. and Lau, C.P. (2003) Angiogenesis in ischaemic myocardium by intramyocardial autologous bone marrow mononuclear cell implantation. Lancet, 361, 47-49. http://dx.doi.org/10.1016/S0140-6736(03)12111-3

[5] Wollert, K.C., Meyer, G.P., Lotz, J., Ringes-Lichtenberg, S., Lippolt, P., Breidenbach, C., et al. (2004) Intracoronary autologous bone marrow cell transfer after myocardial infarction: The BOOST randomised controlled clinical trial. Lancet, 364, 141-148. http://dx.doi.org/10.1016/S0140-6736(04)16626-9

[6] Kang, H.J., Kim, H.S., Zhang, S.Y., Park, K.W., Cho, H.J., Koo, B.K., et al (2004) Effects of intracoronary infusion of peripheral blood stem cells mobilised with granulocyte-colony stimulating factor on left ventricular systolic function and restenosis after coronary stenting in myocardial infarction: The MAGIC cell randomised clinical trial. Lancet, 363, 751-756. http://dx.doi.org/10.1016/S0140-6736(04)15689-4

[7] Fuchs, S., Satler, L.F., Kornowski, R., Okubagzi, P., Weisz, G., Baffour, R., et al. (2003) Catheter based autologous bone marrow myocardial injection in no-option patients with advanced coronary artery disease. Journal of the American College of Cardiology, 41, 1721-1724. http://dx.doi.org/10.1016/S0735-1097(03)00328-0

[8] Perin, E.C., Dohmann, H.F, , Borojevic, R., Silva, S.A., 
Sousa, A.L., et al. (2003) Transendocardial, autologous bone marrow cell transplantation for severe, chronic ischemic heart failure. Circulation, 107, 2294-2302. http://dx.doi.org/10.1161/01.CIR.0000070596.30552.8B

[9] Assmus, B., Schachinger, V., Teupe, C., Britten, M., Lehmann, R., Döbert, N., et al. (2002) Transplantation of progenitor cells and regeneration enhancement in acute myocardial infarction (TOPCARE-AMI) Circulation, 106, 3009-3017.

http://dx.doi.org/10.1161/01.CIR.0000043246.74879.CD

[10] Avilés, F.F., San Román, J.A., García Frade, J, , Valdés. M., Sánchez, A., de la Fuente, L., et al. (2004) Intracoronary stem cell transplantation in acute myocardial infarction. Revista Española de Cardiologia, 57, 201-208. http://dx.doi.org/10.1016/S1885-5857(06)60137-0

[11] Fischer-Rasokat, U., Assmus, B., Seeger, F.H, , Honold, J., Leistner, D., Fichtlscherer, S., et al. (2009) A pilot trial to assess potential effects of selective intracoronary bone marrow-derived progenitor cell infusion in patients with nonischemic dilated cardiomyopathy: Final 1-year results of the transplantation of progenitor cells and functional regeneration enhancement pilot trial in patients with nonischemic dilated cardiomyopathy. Circulation Heart Failure, 2, 417-423. http://dx.doi.org/10.1161/CIRCHEARTFAILURE.109.85 $\underline{5023}$

[12] Balsam, L.B., Wagers, A.J., Christensen, J.L., Kofidis. T., Weissman, I.L. and Robbins, R.C. (2004) Haematopoietic stem cells adopt mature haematopoietic fates in ischaemic myocardium. Nature, 428, 668-673.

http://dx.doi.org/10.1038/nature02460

[13] Murry, C.E., Soonpaa, M.H., Reinecke, H., Nakajima, H., Nakajima, H.O., Rubart, M., et al. (2004) Haematopoietic stem cells do not transdifferentiate into cardiac myocytes in myocardial infarcts. Nature, 428, 664-668. http://dx.doi.org/10.1038/nature02446

[14] van der Bogt, K.E., Sheikh, A.Y., Schrepfer, S., Hoyt, G., Cao, F., Ransohoff, K.J., et al. (2008) Comparison of different adult stem cell types for treatment of myocardialischemia. Circulation. 118, S121-S129. http://dx.doi.org/10.1161/CIRCULATIONAHA.107.7594 $\underline{80}$

[15] Ma, N., Ladilov, Y., Moebius, J.M., Ong, L., Piechaczek, C., Dávid, A., et al. (2006) Intramyocardial delivery of human CD133+ cells in a SCID mouse cryoinjury model: Bone marrow vs. cord blood-derived cells. Cardiovascular Research, 71, 158-169. http://dx.doi.org/10.1016/j.cardiores.2006.03.020

[16] Davy, P., Brienne Walker, B., Wong, L. and Allsopp, R. (2013) Hematopoietic stem cells are a critical sub-population of whole bone marrow in the treatment of myocardial infarction. Stem Cell Discovery, 3, 117-126. http://dx.doi.org/10.4236/scd.2013.32016

[17] Ahmadi, H., Baharvand, H., Ashtiani, S.K., Soleimani, M., Sadeghian, H., Ardekani, J.M., et al. (2007) Safety analysis and improved cardiac function following local autologous transplantation of CD133(+) enriched bone marrow cells after myocardial infarction. Current Neurovascular Research, 4, 153-160. http://dx.doi.org/10.2174/156720207781387141

[18] Kovacic, J.C., Macdonald, P., Feneley, M.P., Muller, D.W., Freund, J., Dodds, A., et al. (2008) Safety and efficacy of consecutive cycles of granulocyte-colony stimulating factor, and an intracoronary CD133+ cell infusion in patients with chronic refractory ischemic heart disease: The G-CSF in angina patients with IHD to stimulate neovascularization (GAIN I) trial. American Heart Journal, 156, 954-963.

http://dx.doi.org/10.1016/j.ahj.2008.04.034

[19] Flores-Ramírez, R., Uribe-Longoria, A., Rangel-Fuentes, M.M., Gutiérrez-Fajardo, P., Salazar-Riojas, R., CervantesGarcía, D., et al. (2010) Intracoronary infusion of CD133+ endothelial progenitor cells improves heart function and quality of life in patients with chronic post-infarct heart insufficiency. Cardiovascular Revascularization Medicine, 11, 72-78.

http://dx.doi.org/10.1016/j.carrev.2009.04.001

[20] Yerebakan, C., Kaminski, A., Westphal, B., Donndorf, P., Glass, A., et al. (2011) Impact of preoperative left ventricular function and time from infarction on the long-term benefits after intramyocardial CD133(+) bone marrow stem cell transplant. Journal of Thoracic and Cardiovascular Surgery, 142, 1530-1539.

http://dx.doi.org/10.1016/j.jtcvs.2011.05.002

[21] Babin-Ebell, J., Sievers, H.H., Charitos, E.I., Klein, H.M., Jung, F., Hellberg, A.K., et al. (2010) Transmyocardial laser revascularization combined with intramyocardial endothelial progenitor cell transplantation in patients with intractable ischemic heart disease ineligible for conventional revascularization: Preliminary results in a highly selected small patient cohort. Journal of Thoracic and Cardiovascular Surgery, 58, 11-16.

http://dx.doi.org/10.1016/j.jtcvs.2011.05.002

[22] Goussetis, E., Manginas, A., Koutelou, M., Peristeri, I., Theodosaki, M., Kollaros, N., et al. (2006) Intracoronary infusion of CD133+ and CD133-CD34+ selected autologous bone marrow progenitor cells in patients with chronic ischemic cardiomyopathy: Cell isolation, adherence to the infarcted area, and body distribution. Stem Cells, 24, 2279-2283. http://dx.doi.org/10.1634/stemcells.2005-0589

[23] Makino, S., Fukuda, K., Miyoshi, S., Konishi, F., Kodama, H., Pan, J., Sano, M., et al. (1999) Cardiomyocytes can be generated from marrow stromal cells in vitro. The Journal of Clinical Investigation, 103, 697-705. http://dx.doi.org/10.1172/JCI5298

[24] Hakuno, D., Fukuda, K., Makino, S., Konishi, F., Tomita, Y., Manabe, T., et al. (2002) Bone marrow derived regenerated cardiomyocytes (CMG cells) express functional adrenergic and muscarinic receptors. Circulation, 105, 380-386. http://dx.doi.org/10.1161/hc0302.102593

[25] Xu, C., Police, S., Rao, N. and Carpenter, M.K. (2002) Characterization and enrichment of cardiomyocytes derived from human embryonic stem cells. Circulation Research, 91, 50-58.

http://dx.doi.org/10.1161/01.RES.0000035254.80718.91

[26] Rangappa, S., Fen, C., Lee, E.H., Bongso, A. and Wei, E.S. (2003) Transformation of adult mesenchymal stem 
cells isolated from the fatty tissue into cardiomyocytes. The Annals of Thoracic Surgery, 75, 775-779. http://dx.doi.org/10.1016/S0003-4975(02)04568-X

[27] Choi, S.C., Yoon, J., Shim, W.J., Ro, Y.M. and Lim, D.S. (2004) 5-azacytidine induces cardiac differentiation of P19 embryonic stem cells. Experimental and Molecular Medicine, 36, 515-523. http://dx.doi.org/10.1038/emm.2004.66

[28] Woodbury, D., Schwarz, E.J., Prockop, D.J. and Black, I.B. (2000) Adult rat and human bone marrow stromal cells differentiate into neurons. Journal of Neuroscience Research, 61, 364-370.

[29] Chen, L.B. Jiang, X.B. and Yang L. (2004) Differentiation of rat marrow mesenchymal stem cells into pancreatic islet beta-cells. World Journal of Gastroenterology, 10, 3016-3020.

[30] Alexanian, A.R., Maiman, D.J., Kurpad, S.N. and Gennarelli, T.A. (2008) In vitro and in vivo characterization of neurally modified mesenchymal stem cells induced by epigenetic modifiers and neural stem cell environment. Stem Cells and Development, 17, 1123-1130. http://dx.doi.org/10.1089/scd.2007.0212
[31] Chugh, A.R., Beache, G.M., Loughran, J.H., Mewton, N., Elmore, J.B., Kajstura, J., et al. (2012) Administration of cardiac stem cells in patients with ischemic cardiomyopathy: The SCIPIO trial: Surgical aspects and interim analysis of myocardial function and viability by magnetic resonance. Circulation, 126, S54-S64. http://dx.doi.org/10.1161/CIRCULATIONAHA.112.0926 $\underline{27}$

[32] Makkar, R.R., Smith, R.R., Cheng, K., Malliaras, K., Thomson, L.E., Berman, D., et al. (2012) Intracoronary cardiosphere-derived cells for heart regeneration after myocardial infarction (CADUCEUS): A prospective, randomised phase 1 trial. Lancet, 379, 895-904. http://dx.doi.org/10.1016/S0140-6736(12)60195-0

[33] Malliaras, K., Makkar, R.R., Smith, R.R., Cheng, K., Wu, E., Bonow, R.O., et al. (2013) Intracoronary cardiosphere-derived cells after myocardial infarction: Evidence for therapeutic regeneration in the final 1-year results of the CADUCEUS trial. Journal of American College of Cardiology, in Press.

http://dx.doi.org/10.1016/j.jacc.2013.08.724 